\title{
Peran Induksi TNF- $\alpha$ Serial Doses dalam Peningkatan VEGF dan PDGF Mesenchymal Stem Cells
}

\author{
Agung Putra, ${ }^{1,3}$ Ananta Hutagalung, ${ }^{2}$ Ihdina Hanifa Hasanal, ${ }^{2}$ Setyo Trisnadi, ${ }^{3}$ Durrotul Djannah, \\ Erwin Budi Cahyono, ${ }^{5}$ Yulice Soraya Nur Intan ${ }^{6}$ \\ ${ }^{1}$ Stem Cell and Cancer Research Institute Fakultas Kedokteran Universitas Islam Sultan Agung Semarang, Indonesia \\ ${ }^{2}$ Mahasiswa Kedokteran Umum, Fakultas Kedokteran Universitas Islam Sultan Agung Semarang, Indonesia \\ ${ }^{3}$ Departemen Pascasarjana Biomedik, Fakultas Kedokteran Universitas Islam Sultan Agung Semarang, Indonesia \\ ${ }^{4}$ Departemen Neurologi, Fakultas Kedokteran Universitas Islam Sultan Agung Semarang, Indonesia \\ ${ }^{5}$ Departemen Ilmu Penyakit Dalam, Fakultas Kedokteran Universitas Islam Sultan Agung Semarang, Indonesia \\ ${ }^{6}$ Departemen Obstreti-Ginekologi, Fakultas Kedokteran Universitas Islam Sultan Agung Semarang, Indonesia
}

\begin{abstract}
Abstrak
Mesenchymal stem cell (MSC) mempunyai kemampuan immunoregulasi dan regenerasi melalui supresi pelepasan mediator proinflamasidan peningkatan molekul proliferasi terutama vascular endothelial growth factor (VEGF) dan platelet-derived growth factor (PDGF). Mesenchymal stem cell yang diaktivasi TNF- $\alpha$ dengan dosis tertentu mampu meningkatkan sekresi VEGF dan PDGF, namun dosis optimal TNF- $\alpha$ yang mampu memaksimalkan ekspresi molekul tersebut belum diketahui secara pasti. Variasi dosis TNF- $\alpha$ digunakan pada penelitian ini dengan tujuan mengetahui dosis optimal, rendah, dan tinggi TNF- $\alpha$ dalam memaksimalkan ekspresi VEGF dan PDGF. Penelitian ini mengunakan post-test only control group design dengan 5 kelompok penelitian, terdiri atas satu kelompok kontrol $(\mathrm{K})$ dan 4 kelompok perlakuan (P) (TNF- $\alpha=5,10,40,80 \mathrm{ng} / \mathrm{mL}$ ) yang diinduksikan pada MSC dengan inkubasi 24 jam, kemudian kadar PDGF dan VEGF diukur dengan metode ELISA. Penelitian ini dilakukan antara bulan September-November 2017 di Laboratorium Stem Cell and Cancer Research (SCCR), Fakultas Kedokteran, Universitas Islam Sultan Agung, Semarang. Hasil penelitian menunjukkan peningkatan kadar PDGF dan VEGF secara signifikan $(\mathrm{p}<0,05)$ dimulai dari dosis TNF- $\alpha 5 \mathrm{ng} / \mathrm{mL}$, optimal padadosis $10 \mathrm{ng} / \mathrm{mL}$ dan mulai terjadi penurunan pada dosis $40 \mathrm{ng} / \mathrm{mL}$. Induksi TNF- $\alpha$ pada MSC mampu memaksimalkan kadar VEGF dan PDGF pada dosis $10 \mathrm{ng} / \mathrm{mL}$.
\end{abstract}

Kata kunci: MSC, PDGF, TNF- $\alpha$, VEGF

\section{Effect of TNF- $\alpha$ Serial Doses Inducition on Increasing VEGF dan PDGF in Mesenchymal Stem Cells}

\begin{abstract}
Mesenchymal Stem Cells (MSCs) have immunoregulation and regeneration capabilities through suppression of proinflammatory mediator release and increase of proliferative molecules, particularly the vascular endothelial growth factor (VEGF) and platelet-derived growth factor (PDGF) TNF- $\alpha$ activated MSC in a certain dose has the ability to increase VEGF and PDGF levels; however, the exact optimum dose of TNF- $\alpha$ to optimize the levels of VEGF and PDGF is unclear. In this study, TNF- $\alpha$ dose variations were used to determine the optimum, low, and high doses of TNF- $\alpha$ in optimizing VEGF and PDGF expression. This was a post-test only control group study with five study groups consisting of one control $(\mathrm{K})$ and four treatment groups(P). The treatment groups were treated with 5, 10, 40 and $80 \mathrm{ng} / \mathrm{mL}$ of TNF- $\alpha$ for 24 hours. PDGF and VEGF levels were measured using ELISA. This study was conducted between September-November 2017 at the Stem Cell and Cancer Research Laboratory (SCCR), Faculty of Medicine, Sultan Agung Islamic University, Semarang. The results show significant increased in PDGF and VEGF levels $(\mathrm{p}<0.05)$ starting from TNF- $\alpha 5 \mathrm{ng} / \mathrm{mL}$ as the initiation dose to $10 \mathrm{ng} / \mathrm{mL}$ as the optimum dose and reduction was seen starting from $40 \mathrm{ng} / \mathrm{mL}$ dose. TNF-induced MSCs have the ability to increase the VEGF and PDGF levels with an optimum dose of $10 \mathrm{ng} / \mathrm{mL}$.
\end{abstract}

Key words: MSC, PDGF, TNF- $\alpha$, VEGF

Korespondensi: Dr. Agung Putra, dr, M.Si. Med, Stem Cell and Cancer Research Institute, Fakultas Kedokteran, Universitas Islam Sultan Agung, Jalan Raya Kaligawe Km. 4, Semarang, Jawa Tengah, Email: dr.agungptr@gmail.com 


\section{Pendahuluan}

Berbagai penelitian melaporkan bahwa vascular endothelial growth factor (VEGF) dan plateletderived growth factor (PDGF) berperan kuat dalam angiogenesis dan proliferasi fibroblast stromal. ${ }^{1,2}$ Kemampuan dari angiogenesis VEGF terjadi melalui pengikatan pada VEGFR sel endothel sehingga menginduksi jalur tyrosine kinase. Induksi jalur tersebut memicu stimulasi berbagai protein, yaitu endothelial nitric oxide synthase (eNOS) dengan fungsi stimulasi permeabilitas vaskuler, basic fibroblast growth factor (bFGF) dengan fungsi proliferasi/survival dan intercellular adhesion molecules (ICAMs), vascular cell adhesion molecules (VCAMs) dan matrix metalloproteinases (MMPs) yang menstimulasi migrasi sel endothel. Rangkaian proses tersebut berakhir dengan terbentuknya pembuluh darah matur. ${ }^{1}$ Sisi lain, ikatan PDGF pada PDGFR sel mural (progenitors), terutama pericytes dan vascular smooth muscle cells (VSMCs) berdampak pada aktivasi jalur extracellular signal regulated kinase $1 / 2$ (ERK $1 / 2$ ) dan berakhir dengan terekspresinya berbagai molekul proregenerasi dan proliferasi jaringan fibroblast ${ }^{2}$.

Konsentrasi VEGF dan PDGF yang rendah menyebabkan terhambat proses penyembuhan luka kronis. Penelitian terdahulu melaporkan bahwa MSCs yang diinduksi TNF- $\alpha$ dengan dosis tertentu mampu meningkatkan sekresi VEGF dan $\mathrm{PDGF}^{3}$ namun pada penelitian tersebut tidak dilakukan variasi dosis TNF- $\alpha$ sehingga dosis optimal yang mampu memaksimalkan ekspresi molekul tersebut belum diketahui secara pasti. Penelitian sebelumnya juga menyatakan bahwa pemberian TNF- $\alpha$ dosis tinggi dapat memicu apoptosis melalui pengikatan pada reseptor TNFrelated apoptosis-inducing ligand (TRAIL) yang merupakan reseptor kematian jalur ekstrinsik, ${ }^{4}$ sebaliknya pada dosis minimal relatif sulit dalam mengaktivasi Mesenchymal stem cell (MSC) ${ }^{1,5}$

Secara teori, MSC merupakan sel punca multipotent yang mengekspresikan berbagai surface marker, yaitu CD73, CD90, dan CD105 disamping sedikit mengekspresikan CD34, CD45, CD14 atau CD11, CD79, atau CD19 dan HLA$\mathrm{DR}^{6}$. Sisi lain, MSC juga mampu berdiferensiasi menjadi berbagai macam tipe sel, diantaranya, osteoblast, kondroblast dan adiposit. ${ }^{7}$ Secara spesifik, gen run-related transcription factor 2 (Runx2), peroxisome proliferator-activated receptor $\gamma$ (PPAR $\gamma$ ), dan juga SRY-box9 (Sox9) berperan dalam differensiasi MSC menjadi osteoblas, kondroblas, dan adiposit. ${ }^{8,9}$ Berbagai penelitian melaporkan MSC dapat diisolasi dari berbagai sumber jaringan, seperti tali pusat, sumsum tulang belakang, adiposa dan cairan amnion. ${ }^{6,8,9}$ Kemampuan MSC meregulasi gangguan inflamasi dan mereparasi kerusakan jaringan membuat penelitian terkait MSCs dalam kurun waktu terakhir semakin tajam.

Immunoregulasi MSC dalam mensupresi inflamasi terjadi melalui pelepasan berbagai molekul bioaktif, seperti interleukin-1 receptor antagonist (IL-1ra), prostaglandin $E_{2}\left(\mathrm{PGE}_{2}\right.$ dan tumor necrosis factor inducible gene-6 (TSG6). ${ }^{10}$ Secara spesifik, IL-1ra yang dilepas MSCs teraktivasi mengikat IL-1R makrofag aktif sehingga efek inflamasi yang ditimbulkan IL-1 mereda. Sisi lain, MSC melalui pelepasan TSG6 menurunkan sinyal toll like receptor/nuclear factor kappa $B$ (TLR2/NF-kB) makrofag aktif dengan mengikat langsung CD44 makrofag sehingga berpolarisasi dari tipe 1 (M1) dengan fenotipe proinflamasi menjadi tipe 2 (M2) dengan profil regenerasi ${ }^{11}$. Sementara melalui pelepasan $\mathrm{PGE}_{2}$, MSC juga mampu menginduksi polarisasi makrofag menjadi tipe 2 yang ditandai dengan pelepasan IL-10 (sitokin anti inflamasi). Proses tersebut dapat terjadi ketika MSCs diinduksi berbagai molekul proinflamasi potent, terutama tumor necrosis factor- $\alpha$ (TNF- $\alpha){ }^{12}$ Fakta ini menunjukkan bahwa MSCs berperan kuat dalam mensupresi inflamasi. Hal tersebut mendorong kami melakukan penelitian terkait variasi dosis TNF- $\alpha$ dalam menginduksi MSC dengan tujuan mengetahui secara pasti dosis optimal TNF- $\alpha$ dalam memaksimalkan ekspresi molekul VEGF dan PDGF.

\section{Metode}

Desain penelitian yang digunakan adalah post-test only control group design. Penelitian ini dilakukan antara bulan September-November 2017 di Laboratorium Stem Cell and Cancer Research (SCCR), Fakultas Kedokteran, Universitas Islam Sultan Agung, Semarang dan telah disetujui oleh Komisi Bioetika Penelitian Kedokteran/ Kesehatan, Fakultas Kedokteran,Universitas Islam Sultan Agung, Semarang No.370/XI/2017/ Komisi Bioetik. Mesenchymal stem cell didapatkan dari tali pusat tikus wistar betina bunting usia 19 hari. Tikus tersebut diperoleh dari Farhan Mouse-Farm Salatiga yang telah disupervisi oleh Dinas Pertanian dengan nomor 524.3/0211/421. Kriteria inklusi yang digunakan adalah MSC mampu menempel pada permukaan cawan kultur pada proses isolasi, mengekspresikan 
marker (+) seperti CD73, CD90, dan CD 105 dan sedikit atau tidak mengekspresikan marker sel haemopoetik, seperti CD14, CD34, CD45, CD11b, CD79a, atau CD19, dan HLA-DR yang dapat berdiferensiasi menjadi osteoblas, adiposit, dan kondroblas.

Tali pusat tikus betina hamil 19 hari dicuci dengan larutan PBS. Pembuluh darah tali pusat dibuang kemudian tali pusat dipotong kecil 2-5 $\mathrm{mm}$ dengan pisau steril dan diletakkan secara merata dalam cawan kultur $66 \mathrm{~mm}$. Medium yang digunakan adalah medium kultur DMEM (Sigma-Aldrich, Louis St, MO) dicampur dengan 10\% PBS, $100 \mathrm{IU} / \mathrm{mL}$ penisilin/streptomysin (GIBCO, Invitrogen) kemudian diinkubasi pada suhu $37^{\circ} \mathrm{C}$ dengan $5 \% \mathrm{CO}_{2}$. Penggantian medium dilakukan setiap 3 hari.

Ekspresi MSC hasil isolasi dinilai dengan teknik immunocytochemistry menggunakan MSC-positif marker. Setelah MSC konfluen 60-80\%, MSC dipanen dan juga ditumbuhkan di coverslips kemudian di fiksasi dengan 4\% paraformaldehyde dalam $90 \%$ ethanol selama 15 menit dan suhu $4^{\circ} \mathrm{C}$. Sel diinkubasi dengan antibodi primer CD 73 dan CD 105 (1:100; BD Pharmingan, San diego, CA) selama 60 menit dalam suhu ruang, dicuci dengan PBS selama 10 menit kemudian ditambahkan antibodi sekunder (1:2.500) selama 15 menit dalam suhu ruang kemudian dilakukan counterstaining dengan DAB (Santa Cruz Biotech) dan diamati dengan mikroskop.

Mesenchymal stem cell ditanam dalam cawan kultur dengan kerapatan $5 \times 10^{3} / 1 \times 10^{4} \mathrm{sel} /$ well diberi perlakuan medium induksi osteogenik yang berisi $10 \mathrm{mmol} / \mathrm{L} \beta$ glycerophospate, $10^{-7}$ mol/ L/0,1 $\mu \mathrm{M}$ dexamethasone, $50 \mu \mathrm{mol} / \mathrm{L}$ ascorbate-2-phosphate (Sigma-Aldrich, Louis St, MO) dan 10\% FBS dalam DMEM. Differensiasi osteogenik diamati dengan pewarnaan alazarin red setelah 21 hari induksi untuk mengetahui deposit kalsium. Sel dibilas dengan PBS dan difiksasi dengan etanol dingin $70 \%(\mathrm{v} / \mathrm{v})$ selama 1 jam di dalam suhu ruang, kemudian dibilas tiga kali dengan akuabides. Larutan alizarin red sebanyak $1 \mathrm{~mL}$ dari $2 \%$ (w/v) (pH 4,1-4,3) ditambahkan dan diinkubasi selama 30 menit dalam suhu ruang kemudian dibilas empat kali dengan akuabides.

Mesenchymal stem cell $\left(1 \times 10^{4}\right.$ sel/well $)$ disuplementasi dengan TNF- $\alpha$ rekombinan $(2,5$, 5, 10, 40, dan $80 \mathrm{ng} / \mathrm{mL}$, BioLegend, San Diego, CA) dalam 24-well plate menggunakan medium $\alpha$ MEM (Sigma-Aldrich, Louis St, MO) kemudian diinkubasi selama 24 jam pada suhu $37^{\circ} \mathrm{C}$ dengan $5 \% \mathrm{CO}_{2}$. Medium hasil inkubasi TNF- $\alpha$ rekombinant tersebut, kemudian dikumpulkan dan dilakukan pengujian kadar PDGF dan VEGF.

Uji kadar PDGF dan VEGF medium dengan ELISA kit (Fine test, China) dilakukan sesuai petunjuk penggunaan pada suhu ruang. Plate ELISA dilapisi dengan capture antibody dan diinkubasi semalam pada suhu $4^{\circ} \mathrm{C}$. Sumuran dicuci kemudian diblok selama 1 jam. Sumuran diinkubasi dengan larutan standar PDGF dan VEGF rat, medium perlakuan dan medium kontrol selama 2 jam, diencerkan dengan perbandingan 1:100 hingga didapatkan pengukuran dalam kurva standar. Setelah pencucian, sumuran diinkubasi dengan antibodi deteksi selama satu jam, kemudian dicuci kembali beberapa kali. Sumuran diinkubasi dengan avidin-HRP selama 30 menit, dicuci bersih, diinkubasi dengan substrat solution selama 15 menit, diikuti dengan penambahan stop solution, dan hasil dianalisis pada panjang gelombang $\mathrm{A}_{450}$ mempergunakan microplate reader.

Data ditampilkan dalam bentuk rerata. Kadar PDGF dan VEGF dianalisis menggunakan SPSS 16.0 for windows. Uji normalitas menggunakan uji Saphiro-wilk dan uji homogenitas menggunakan uji Levene's statistik. Uji beda parametrik dilakukan dengan analysis of variance (ANOVA) dan dilanjutkan dengan duncan multiple range test (DMRT).

\section{Hasil}

Mesenchymal stem cell diisolasi secara in vitro membentuk berbagai klon sel dan terus tumbuh memenuhi lapang pandang hingga konfluen $80 \%$ (Gambar 1a). MSC yang konfluen dikarakterisasi mempergunakan teknik immunocytochemistry menunjukkan ekspresi berbagai protein surface marker positif, terutama CD105 (Gambar 1b) dan CD73 (Gambar 1c). Hal ini ditandai dengan kemunculan warna coklat pada populasi MSC. Uji diferensiasi menunjukkan hasil bahwa MSC mampu berubah menjadi sel osteogenik yang ditunjukkan denganwarna merah hasil pewarnaan alizarin red staining pada populasi MSC yang diberi medium osteogenik (Gambar 1d).

Hasil induksi TNF- $\alpha$ pada MSC menunjukkan ekspresi sitokin proliferasi berupa VEGF (Gambar 2) dan PDGF (Gambar 3). Analisis konsentrasi VEGF menunjukkan terdapat peningkatan yang signifikan pada semua perlakuan $(p<0,001)$. Peningkatan konsentrasi VEGF dimulai dari perlakuan TNF- $\alpha$ dosis $5 \mathrm{ng} / \mathrm{mL}(370,04 \pm 3,29 \mathrm{pg} /$ $\mathrm{mL}$ ) yang mencapai optimum pada TNF- $\alpha$ dosis 


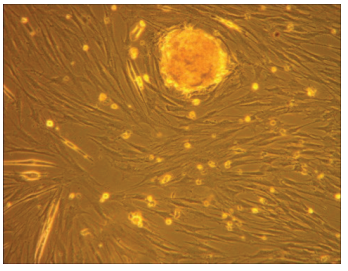

(a)

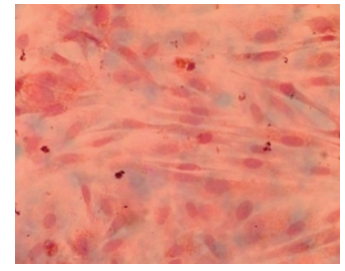

(b)

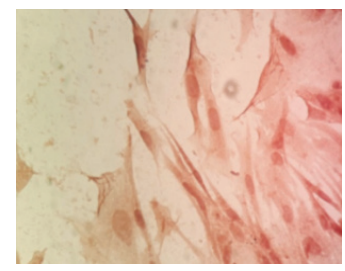

(c)

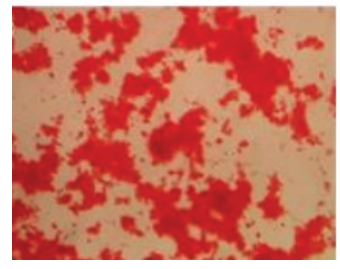

(d)

Gambar 1 (a) Gambar MSC tali pusat hasil kultur in vitro perbesaran 10x, tampak sel berbentuk seperti fibroblas; (b) Karakteristiasi MSC hasil kultur perbesaran 100x, tampak sel berwarna coklat yang menandakan bahwa sel tersebut mengekspresikan CD 105 (+); dan (c) CD 73(+); (d) Uji diferensiasi osteogenikdengan medium osteogenik tampak warna merah pada populasi MSC (pewarnaan alizarin red staining).

$10 \mathrm{ng} / \mathrm{mL}(497,86 \pm 1,50 \mathrm{pg} / \mathrm{mL})$ dan menurun pada TNF- $\alpha$ dosis $40 \mathrm{ng} / \mathrm{mL}(440,34 \pm 2,06 \mathrm{pg} /$ $\mathrm{mL})$ dan $80 \mathrm{ng} / \mathrm{mL}(397,86 \pm 2,51 \mathrm{pg} / \mathrm{mL})$. Sisi lain, peningkatan signifikan juga ditunjukkan pada hasil analisis konsentrasi PDGF pada semua perlakuan $(\mathrm{p}<0,001)$. Konsentrasi PDGF ini juga mulai meningkat pada dosis $5 \mathrm{ng} / \mathrm{mL}$ $(285,28 \pm 3,07 \mathrm{pg} / \mathrm{mL})$ dan mencapai optimal pada TNF- $\alpha$ dosis $10 \mathrm{ng} / \mathrm{mL}(331,67 \pm 1,74 \mathrm{pg} /$ $\mathrm{mL}$ ). Konsentrasi PDGF juga meningkat pada dosis $40 \mathrm{ng} / \mathrm{mL}(268,67 \pm 1,60 \mathrm{pg} / \mathrm{mL})$ dan 80 $\mathrm{ng} / \mathrm{mL}(243,01 \pm 1,54 \mathrm{pg} / \mathrm{mL})$, namun kadarnya lebih rendah dari dosis $5 \mathrm{ng} / \mathrm{mL}$.

\section{Pembahasan}

Penyembuhan luka kronik ini masih menjadi masalah kesehatan di dunia dengan angka kejadian 5-7 juta kasus per tahunnya di Amerika Serikat, 50\% diantaranya tidak merespon dengan terapi yang ada. Sulitnya pembentukan jaringan baru pada luka kronik yang persisten diduga akibat tidak aktifnya sel punca endogenus dalam mengoordinasikan proses regenerasi. ${ }^{16}$ Proses tersebut dimulai dengan MSC yang mensupresi fase inflamasi melalui pelepasan berbagai molekul bioaktif dengan tujuan mempercepat proses inflamasi menuju fase proliferasi. Hal ini ditunjukkan dengan peningkatan jumlah VEGF dan PDGF serta sel fibroblas pada sekitar area injury. ${ }^{7}$

Mesenchymal stem cell berperan sebagai guardian inflamasi dengan cara meningkatkan berbagai molekul anti-inflamasi, di antaranya IL-1ra, TSG-6, PGE ${ }_{2}$ IL-10, dan TGF $\beta$ yang

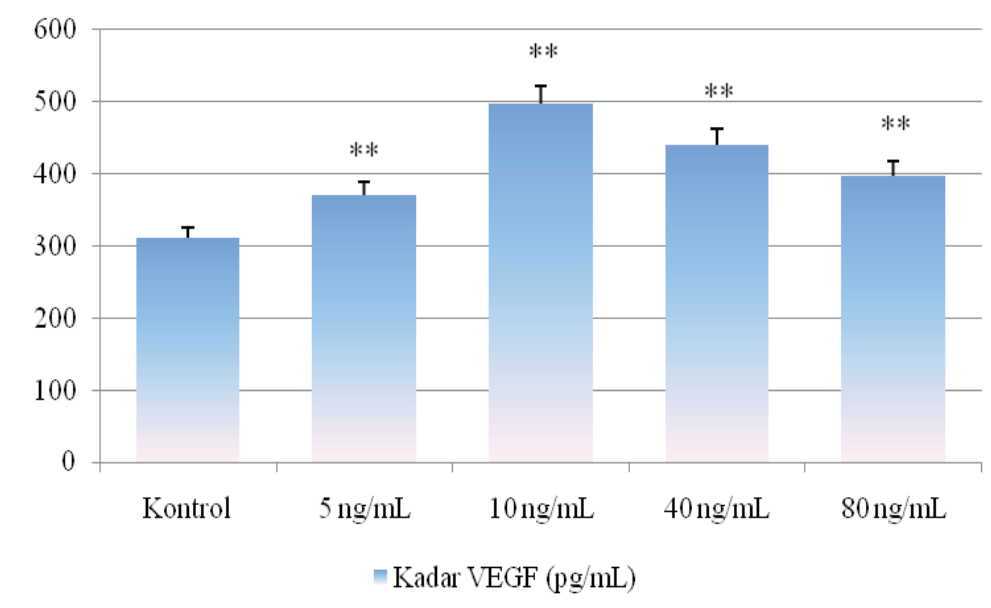

Gambar 2 Kadar VEGF pada Medium MSC yang Telah Diaktivasi TNF- $\alpha$ dengan Dosis 5, 10, 40, dan 80 ng/mL. Kadar TNF- $\alpha 10$ ng/mL Menunjukkan Peningkatan Kadar VEGF (497,85 pg/ mL) Paling Optimal $* *$ p $<0,001$ 


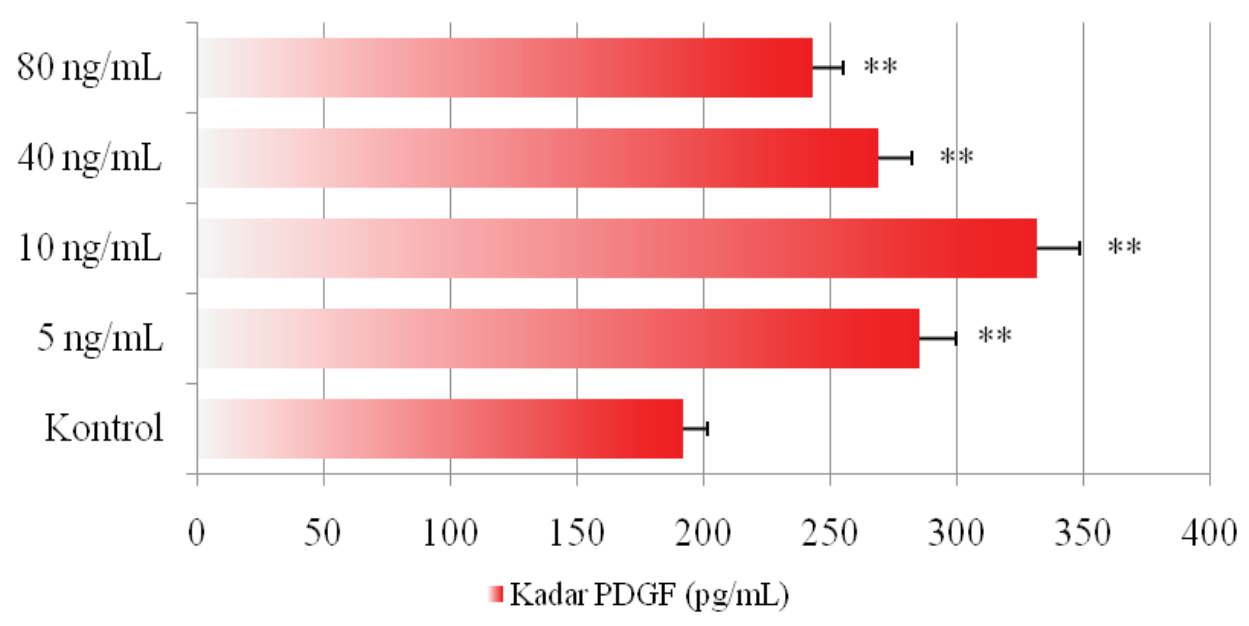

\section{Gambar 3 Kadar PDGF pada Medium MSC yang Telah diaktivasi TNF- $\alpha$ dengan Dosis 5, 10, 40, dan 80 ng/mL. Kadar TNF- $\alpha 10$ ng/mL Menunjukkan Peningkatan Kadar PDGF $(331,67 \pm 1,74 \mathrm{pg} / \mathrm{mL})$ Paling Optimal.** $\mathrm{p}<0,001$}

berakibat pada penurunan mediator inflamasi terutama molekul TNF- $\alpha .{ }^{17}$ Penelitian terdahulu melaporkan bahwa MSC yang diaktivasi TNF- $\alpha$ dengan dosis tertentu mampu menstimulasi regenerasi melalui peningkatan ekspresi VEGF dan PDGF, namun pada penelitian tersebut tidak dilakukan variasi dosis TNF- $\alpha$ sehingga dosis optimal yang mampu memaksimalkan ekspresi molekul tersebut belum diketahui secara pasti. Proses infamasi secara natural melibatkan berbagai sel, diantaranya makrofag, limfosit, dan neutrofil yang secara sequencial menghasilkan berbagai mediator inflamasi, diantaranya TNF- $\alpha$. Molekul tersebut mampu mengaktivasi berbagai sel radang termasuk MSC sehingga proses regenerasi berjalan optimal ${ }^{7}$.

Hasil penelitian kami menunjukkan bahwa terdapat peningkatan kadar VEGF dan PDGF pada MSC yang diaktivasi TNF- $\alpha$. Kadar VEGF dan PDGF paling optimal diekspresikan oleh MSC yang diaktivasi $10 \mathrm{ng} / \mathrm{mL}$ TNF- $\alpha$. Kami menduga dosis tersebut mampu memicu lingkungan inflamasi yang optimal dalam mengaktivasi MSC tanpa menyebabkan apoptosis, sehinggasekresi PDGF dan VEGF meningkat. Hal ini sesuai dengan penelitian terdahulu yang melaporkan bahwa induksi TNF- $\alpha$ hingga dosis $50 \mathrm{ng} / \mathrm{mL}$ tidak menyebabkan apoptosis pada $\mathrm{MSC}^{14}$.Secara teoritis, TNF- $\alpha$ memicu transkripsi berbagai gen MSC terutama gen yang terkait dengan angiogenesis dan proliferasi. Proses ini dimulai dengan berikatannya TNF- $\alpha$ pada TNF- $\alpha$ receptor associated factor (TRAF) sehingga menstimulasi aktivasi PI3K/Akt pathway dan menimbulkan fosforilasi kompleks inhibitor of NF- $\kappa \mathrm{B}$ (IкB) Kinase (IKK), diantaranya IkB $\alpha$. DegradasilkB $\alpha$ memungkinkan subunit NF-kB, p50, dan p65 bertranslokasi menuju nukleus yang berdampak pada peningkatan aktivitas transkripsi gen dan mengoptimalkan sekresi VEGF dan PDGF. ${ }^{15,18}$

Hasil penelitian ini juga menunjukkan bahwa dosis minimal yang mampu menstimulasi kadar PDGF dan VEGF adalah $5 \mathrm{ng} / \mathrm{mL}$. Hal ini sesuai dengan penelitian lain yang melaporkan bahwa induksi TNF- $\alpha$ dosis rendah pada MSC mampu mengaktivasi jalur canonical NF-KB dan p38 MAPK $^{19}$ sehingga mengekspresi VEGF dan PDGF. Sisi lain, induksi TNF- $\alpha$ dosis tinggi dapat meningkatkan sekresi MCP-1 yang berdampak pada apoptosis MSC. ${ }^{13}$ Hal ini sesuai dengan penelitian kami di mana kadar VEGF dan PDGF mulai mengalami penurunan pada dosis 40 $\mathrm{ng} / \mathrm{mL}$ hingga $80 \mathrm{ng} / \mathrm{mL}$. Proses apoptosis diduga telah terjadi pada konsentrasi tersebut, namun pada penelitian ini tidaklah melakukan pemeriksaan apoptosis secara molekuler sehingga penyebab pasti penurunan kadar VEGF dan PDGF pada dosis TNF- $\alpha 40 \mathrm{ng} / \mathrm{mL}$ dan 80 $\mathrm{ng} / \mathrm{mL}$ belum dapat diketahui. Kami juga tidak melakukan penelitian terkait pemberian dosis TNF- $\alpha$ di bawah $5 \mathrm{ng} / \mathrm{mL}$ dan di atas $80 \mathrm{ng} / \mathrm{mL}$ sehingga kami tidak mengetahui secara pasti pengaruh TNF- $\alpha$ pada dosis tersebut. Untuk itu, perlu dilakukan penelitian lebih lanjut terkait 
pemberian dosis TNF- $\alpha$ di bawah $5 \mathrm{ng} / \mathrm{mL}$ dan di atas $80 \mathrm{ng} / \mathrm{mL}$ pada MSC serta pemeriksaan molekuler jalur tirosin kinase dan apoptosis dalam menunjang hal tersebut.

Simpulan, kadar VEGF dan PDGF paling optimal diekspresikan oleh MSC yang diaktivasi pada dosis $10 \mathrm{ng} / \mathrm{mL}$ TNF- $\alpha$. Dosis tersebut diduga mampu memicu lingkungan inflamasi yang optimal dalam mengaktivasi MSC tanpa menyebabkan apoptosis, sehingga sekresi PDGF dan VEGF meningkat.

\section{Ucapan Terima Kasih}

Ucapan terima kasih ditujukan kepada Pimpinan Stem Cell and Cancer (SCCR) Institute, Uni Riset dan Pengabdian Masyarakat (URPM) Universitas Islam Sultan Agung (UNISSULA) dan Departemen Pascasarjana Biomedik, Fakultas Kedokteran UNISSULA atas izin dan fasilitas pendukung dalam penelitian ini.

\section{Daftar Pustaka}

1. Semenov OV, Koestenbauer S, Riegel M, Zech $\mathrm{N}$, Zimmermann R, Zisch AH. Multipotent mesenchymal stem cells from human placenta: critical parameters for isolation and maintenance of stemness after isolation. Am J Obstet Gynecol. 2010;202(2):193.

2. Ringe J, Leinhase I, Stich S, Loch A, Neumann $\mathrm{K}$, Haisch A. Human mastoid periosteumderived stem cells: promising candidates for skeletal tissue engineering. J Tissue Eng Regen Med. 2008;2:136-46.

3. Tominaga H, Maeda S, Miyoshi H, Miyazono K, Komiya S, Imamura T. Expression of osterix inhibits bone morphogenetic proteininduced chondrogenic differentiation of mesenchymal progenitor cells. J Bone Miner Metab. 2009;27:36-45.

4. Akiyama H. Control of chondrogenesis by the transcription factor Sox9. Mod Rheumatol. 2008;18:213-9.

5. Shen B, Wei A, Tao H, Diwan $\mathrm{AD}, \quad \mathrm{Ma}$ DD. BMP-2 enhances TGF-beta3-mediated chondrogenic differentiation of human bone marrow multipotent mesenchymal stromal cells in alginate bead culture. Tissue Eng Part A. 2009;15:1311-20.

6. Raica M, Cimpean AM. PDGF platelet-derived growth factor (PDGF)/PDGF receptors
(PDGFR) axis as target for antitumor and antiangiogenic marius. Therapy. 2010;57299.

7. Karin M, Clevers H. Reparative inflammation takes charge of tissue regeneration. Nat Med. 2016;529(7586):307-15.

8. Broekman W, Amatngalim GD, Mooij-Eijk YD, Oostendorp J, Roelofs H, Taube C. Respiratory Research TNF- $\alpha$ and IL-1 $\beta$-Activated Human Mesenchymal Stromal Cells Increase Airway Epithelial Wound Healing In Vitro via Activation of The Epidermal Growth Factor Receptor. 2016;17:3.

9. Sioud M, Mobergslien A, Boudabous A, Fløisand Y. Evidence for the Envolvement of galectin-3 in mesenchymal stem cell suppression of allogeneic T-cell proliferation. Scand J Immunol. 2010;71:267-74.

10. Carmeliet P, Ruiz DAC. VEGF ligands and receptors: implications in neurodevelopment and neurodegeneration. Cell Mol Life Sci 2013; 70:1763.

11. KochS, Claesson-Welsh L. Signal transduction by vascular endothelial growth factor receptors. Cold Spring Harb Perspect Med. 2012;2:6502.

12. Chen $\mathrm{H}$, Min $\mathrm{X}$, Wang $\mathrm{Q}$, Leung FW, Shi L, Zhou Y. Pre-Activation of Mesenchymal Stem Cells With TNF- $\alpha$, IL-1 $\beta$ And Nitric Oxide Enhances Its Paracrine Effects on RadiationInduced Intestinal Injury. Scientific Reports 2015;5:8718.

13. Li X, Du W, Ma FX, Feng X, Bayard F, Han ZC. High Concentrations of TNF- $\alpha$ Induce Cell Death during Interactions between Human Umbilical Cord Mesenchymal Stem Cells and Peripheral Blood Mononuclear Cell. Plos One. 2015;10:1371.

14. Jahromi SH, Li Y, Davies JE. Effect of Tumor Necrosis Factor Alpha Dose and Exposure Time on Tumor Necrosis Factor Induced Gene-6 Activation by Neonatal and Adult Mesenchymal Stromal Cells. Stem Cells and Development. 2017;10:1089.

15. Egea V, Baumgarten LV, Schichor C, Berninger B, Popp T, Goldbrunner R. TNF- $\alpha$ respecifies human mesenchymal stem cells to a neural fate and promotes migration toward experimental glioma. Cell Death and Differentiation. 2011;18:853-683.

16. HansonSE, Bentz ML, Hematti P. Mesenchymal stem cell therapy for nonhealing cutaneous wounds. Plast Reconstr Surg. 2010;125: 510-516

17. Prockop DJ, Oh JY. Mesenchymal Stem/ Stromal Cells (MSCs): Role as Guardians of 
Inflmmation. The American Society of Gene \& Cell Therapy. 2012; 20(1):14-20.

18. Ridiandries A, Tan JTM and Bursill CA. The Role of CC-Chemokines in the Regulation of
Angiogenesis. IJMS. 2016;17:1856.

19. Ghosh, S, Hayden, MS, Celebrating 25 years of NF-кB research. Immunol. Rev. 2012;246:513. 